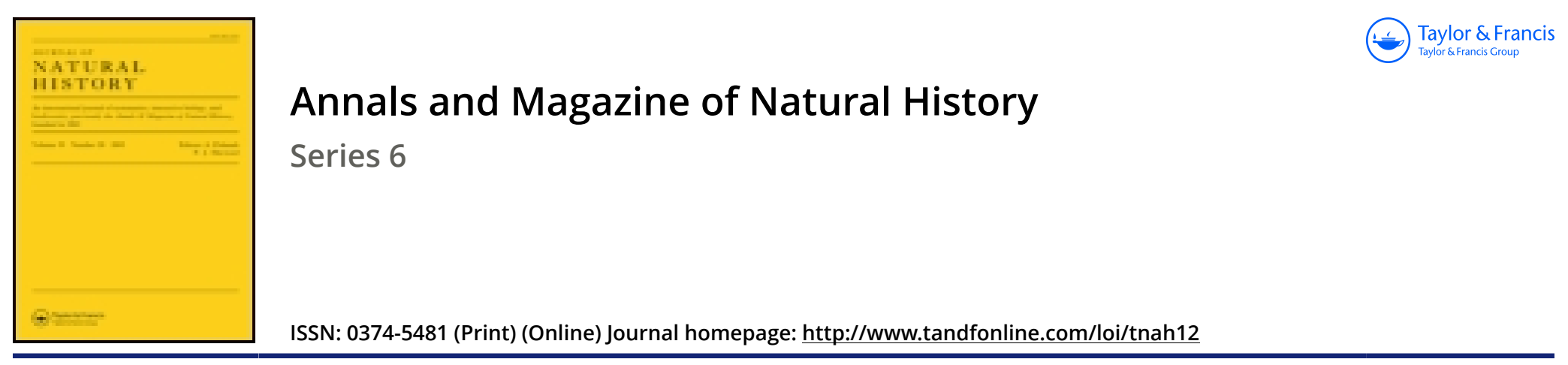

\title{
Note on the relative claims to recognition of the generic names Arbacia, Gray, and Echinocidaris, Des Moulins
}

\section{F. Jeffrey Bell}

To cite this article: F. Jeffrey Bell (1889) Note on the relative claims to recognition of the generic names Arbacia, Gray, and Echinocidaris, Des Moulins, Annals and Magazine of Natural History, 3:15, 290-290, DOI: 10.1080/00222938909460330

To link to this article: http://dx.doi.org/10.1080/00222938909460330

曲 Published online: 09 Oct 2009.

Submit your article to this journal $\pi$

Џll Article views: 3

Q View related articles $\sqsubset$ 


\section{MISCELLANEOUS.}

Note on the Relative Claims to Recognition of the Generic Names Arbacia, Gray, and Echinocidaris, Des Moulins. By F. JEFFRex BELL.

Is the year 1835 Dr. J. E. Gray and M. Des Moulins gave respectively the names Arbacia and Echinocidaris to the same type of Echinoids. The latter claimed priority *, "puisque mon Tableau synoptique des genres . . . a été publié en août 1835," while, he says, the name of Gray was not published till October 1835. Mr. A. Agassiz, in his 'Revision of the Echini' (p. 90), gave the priority to Gray, adding to his name "April," to Des Moulins's "July : " these months mark, however, only the date of reading; the date of publication, which is quite another matter, was for Des Moulins's name August 15; that of Gray's name cannot be definitely asserted from the contents of the 'Proceedings of the Zoological Saciety' for 1835, and the only known date was the republication in the October number of the 'Philosophical Magazine.' I have now to say that at my request Mr. Williams, of the Zoological Society, has instituted a search through their records, and finds that the sheet containing Gray's paper "was delivered to the Society at their rooms on the 17 th July, 1835. In those days sheets so soon as printed off were distributed to the Fellows." I am afraid, therefore, the case for Gray's nonsense name as against Des Moulins's happy suggestion is complete and that we cannot avoid using the name Arbacia.

On the presence of Spinnerets in the Myriopoda.

By M. Jules Chalaude.

One of the principal characters of the Araneida consists in the presence at the extremity of the abdomen of spinnerets, or tubes, serving for the outflow of the secretion of spinning-glands. The existence of analogous organs has not hitherto been demonstrated in the Myriopoda, although M. Fabre, of Avignon, having remarked that the spermatophores of the Geophili are deposited upon nets composed of threads like those of spiders, concluded that the Chilopoda must spin these themselves with the secretion of their genital glands $\uparrow$. My observations upon those animals have not yet furnished me with exact facts demonstrative of the opinion expressed by the above acute observer.

I have been more fortunate with another species, Scolopendrella immaculata, Newport. This Myriopod, which has been separated from the order Chilopoda to form that of the Symphila (Latzel), presents the remarkable peculiarity of possessing an apparatus

* 'Etudes sur les Echinides,' p. 304.

† Aun. Sci. Nat. sér. 4, tom. iil. p. 30.s. 